\title{
Union leader's language during conflict: Does gender matter?
}

\author{
Charles Keim \\ School of Business \\ MacEwan University \\ Edmonton, Alberta \\ T5J 4S2 CANADA \\ Email: keimc@macewan.ca \\ Canada \\ Yonatan Reshef \\ School of Business \\ University of Alberta \\ Edmonton, Alberta \\ T6G 2R6 CANADA \\ Email: yreshef@ualberta.ca \\ Canada
}

Vol: 2, Issue: 6

June/2021

https://ijbssrnet.com/index.php/ijbssr

DOI: http://dx.doi.org/10.47742/ijbssr.v2n6p1

\begin{abstract}
A B S T R A C T
We analyze the language used by two consecutive British Columbia Teachers' Federation (BCTF) presidents, Susan Lambert and Jim Iker, during two collective bargaining sessions that pitted the BCTF against the British Columbia (BC) government and the British Columbia Public School Employers' Association (BCPSEA). Our study analyzes how gender language differences if they indeed exist, are manifested during critical moments that require strong leadership. Language is a critical resource for leaders, who use it to define issues, assign motives and inspire action, and portray themselves as people of power and consequence. Both women and men can employ a variety of linguistic strategies and the linguistic decisions that male and female leaders make provide a window onto if and how gender may be manifested by those in power and how they use language to present themselves as effective leaders. In this paper, we explore whether and how gender influences the linguistic choices of a male and female union leader during times of conflict.

Keywords: discourse; gender; conflict; public sector; unions; leadership
\end{abstract}

\section{Introduction}

We analyze the language used by two consecutive British Columbia Teachers' Federation (BCTF) presidents, Susan Lambert and Jim Iker, during two collective bargaining sessions pitting the BCTF against the British Columbia (BC) government and the British Columbia Public School Employers' Association (BCPSEA). Language is a critical resource for leaders, who use it to define issues, assign motives and inspire action, and portray themselves as people of power and consequence. Indeed, every time leaders speak they must make "a linguistic choice about how to perform leadership" (Baxter,2010: 12). We ask whether gender influences the language union leaders used during labor conflict. Popular definitions of leadership have been largely constructed in "culturally masculine terms that disfavor women" (Eagly \& Heilman, 2016:349). For example, in their recent study of women leaders, Hoyt and Murphy (2016: 388) find the "particular gender stereotypes most relevant to the domain of leadership are those maintaining that 'women take care' and 'men take charge."' Less clear, however, is how, or if, these stereotypes are revealed in the linguistic choices that male and female leaders make during labor conflict.

We examine the language that a male and female union president used when publicly addressing their members, and other stakeholders, in two consecutive conflicts with the same government antagonist. In so doing, we answer Kirton and Healy's(2012:996) call for further research “comparing women's and men's union leadership discourses and orientations [to] unpack gendered leadership." Our study analyzes how gender language differences if they indeed exist, are manifested during critical moments that require strong leadership.

The recent conflicts between the British Columbia Teachers' Federation (BCTF) and the government of British Columbia (2011-14) provide the context for our inquiry. Despite the female-dominated constitution of the BCTF (approximately $70 \%$ female), of the 70 individuals who served as president only $8(11.43 \%)$ have been female, exemplifying the caricature of union leadership as "male, pale and stale" (Kirton \& Healy, 2012). During the initial phase of the studied conflicts (2011-12), 
Vol: 2, Issue: 6

June/2021

https://ijbssrnet.com/index.php/ijbssr

DOI: http://dx.doi.org/10.47742/ijbssr.v2n6p1

Susan Lambert served as president of the BCTF while Jim Iker presided during the latter one (2013-14). We use these two conflicts between the $\mathrm{BCTF}$ and the $\mathrm{BC}$ government to explore how the female and male union presidents used language to enact their leadership.

\section{Gender and Leadership}

In her classic study, Men and Women of the Corporation, Rosabeth Moss Kanter (1977: 22) spoke of the 'masculine ethic' which privileged those leadership traits said to belong to men: "a tough-minded approach to problems; analytic abilities to abstract and plan; a capacity to set aside personal, emotional considerations in the interests of task accomplishment.' More recently, Kirton and Healy (2012:981) have summarized traditional views of feminine leadership as "interpersonally oriented, democratic, collaborative and transformational, which contrasts with masculine leadership, defined as task-oriented, authoritarian, controlling and transactional." Some have associated the latter view with the expression of manhood as "a man in power, a man with power, and a man of power" (Kimmel, 1994:125). The male-dominated leadership paradigm functioned as an 'exclusionary principle prohibiting women from formal positions of power' which, in turn, robbed organizations of valuable skills simply because they were perceived as feminine (Mumby, 1998; Mumby \& Putnam, 1992).

Kanter (1977) argued that women were judged by their gender, not their expertise or achievement, and assigned to one of four male-sanctioned roles: Mother, Seductress, Pet, or Iron Maiden. These roles restricted women's leadership potential and placed them in a bind. Using their "native tongue" condemned them to a role that was not suited for leadership; but if they used masculine language, they were discounted as unfeminine (Iron Maiden), and charged with lacking the soft skills necessary for leadership (Cobble, 2004; Kirton, 2006; Williams, 2002). This dilemma has been captured succinctly by Tannen (1990: 244): "[t]he road to authority is tough for women, and once they get there it's a bed of thorns."

Recent language and gender studies looking at the workplace (e.g. Holmes \& Stubbe 2003; Holmes 2006; Mullany 2007; Schnurr 2008) continue to challenge our understanding of gender and leadership, finding that leadership is situated. In response to a specific situation, effective leaders draw from a wide repertoire of communicative strategies to achieve their goals. Thus in studying the language leaders use to respond to adversity Korabik (1990) has found men who routinely adopt feminine styles and women who adopt masculine speech styles. Perhaps leadership, therefore, is more an activity than an attribute, in which both females and males exhibit skill in selecting the appropriate language for a particular context. So considered, leadership becomes a fluid space in which speakers, regardless of their gender, use language to respond to the demands of the situation and the needs of their audience.

Consequently, Baxter has argued for the Reconceptualizing of "roles" as "subject positions" (2012: 84) to "indicate the tension between actively positioning oneself as a speaker and being positioned by accepted discursive practices to speak and respond in given ways" (emphasis in the original). For Baxter (2012:102), linguistic practices need not condemn women to "role traps," but rather each role offers a repertoire of linguistic resources to provide "senior women a range of voices and a means of resistance at moments when they are in danger of being undermined." Language, so considered, is the golden key promising to unlock the door to effective leadership.

Analytically, Baxter (2010: 74) argues that gender may be more realistically seen as a continuum with some overlap between the sexes rather than as two polarized categories. Both women and men can employ a variety of linguistic strategies to position themselves as leaders of import. For Baxter, language is the principal reason why women continue to be underrepresented in senior leadership, and she recommends that women become "linguistic experts ... [able] to discern which combination and 'weighting' of strategies are most appropriate for their audience, context, and purpose" (2010: 174). In so doing they can establish themselves as leaders of excellence and serve as role models for women across the organizational spectrum.

A study of gender and leadership thus requires close attention to the language that leaders use when performing leadership and the context within which it is used. The linguistic decisions that male and female leaders make provide a window into if and how gender may be manifested by those in power and how they use language to present themselves as effective leaders. In this paper, we explore whether and how gender influences the linguistic choices of a male and female union leader in a time of conflict.

\section{Background}

The acrimonious relationship between the $B C$ government and the BCTF has been described as "a conflict that has been, without question, the single most defining characteristic of public education in the province for the past four decades" (Fleming 2011: 12). Although our analysis covers more recent events, important earlier developments deserve note (for a fuller account see Reshef and Keim, 2016). In August 2001, responding to deadlocked wage bargaining between the province's 45,000 teachers and their provincial employer, the provincial government passed Bill 18 (Skills Development and Labor Statutes Amendment Act), which designated education an essential service. Still, the teachers began the 2001-02 school year by withdrawing from a Labor Relations Board (LRB)approved list of extracurricular services, which included not issuing report cards. In January of 2002, the government passed two bills, Bill 27, the Education Services Collective Agreement Act, which imposed the employers' first and only offers, and Bill 28, Public Education Flexibility and Choice Act, which diminished the union's bargaining capacity by removing staffing levels and class size and composition from the bargaining table.

The BCTF quickly appealed to the BC Supreme Court, alleging that the two bills violated the teachers' freedom of association, which was protected by the Canadian Charter of Rights and Freedoms. Since at that time several BC healthcare unions had made a similar appeal to the Supreme Court of Canada, the BC court chose to defer its decision. In 2007, in a 
Vol: 2, Issue: 6

June/2021

https://ijbssrnet.com/index.php/ijbssr

DOI: http://dx.doi.org/10.47742/ijbssr.v2n6p1

landmark decision, the Supreme Court of Canada declared that collective bargaining was protected by the Charter. Therefore, governments could not tear up duly negotiated collective agreements (Health Services and Support, 2007). In April of 2011, in step with the 2007 decision, Justice Griffin of the BC Supreme Court found in the teachers' favor and gave the province a year to fix the flawed 2002 legislation (British Columbia Teachers' Federation, 2011).

The next negotiation round, in 2010, was overshadowed by the government net-zero mandate, which stipulated that any financial improvements in the public sector collective agreements had to be offset by savings in other compensation areas, resulting in no net increase in total compensation costs. Nonetheless, the union asked for a 15.0 percent wage increase over three years and, following the April 2011 court ruling, renewed negotiations over staffing levels, class size, and composition. The government rejected these demands.

The teachers began the 2011-'12 school year with job action, which included not issuing report cards. In late February 2012, after more than 70 negotiation sessions, the government introduced Bill 22 (The Education Improvement Act). It implemented a new Learning Improvement Fund of \$165 million over three years to help school districts and teachers address classroom composition issues and imposed a six-month coolingoff period. During this period, a government-appointed mediator would try to help the parties reach an agreement. In addition, it imposed steep fines for strike action during the cooling-off period and forced the mediator to abide by the net-zero mandate. Although staffing levels, class size, and composition should have been restored to the bargaining table (per the BC Supreme Court Judge Griffin ruling), the mediator was prohibited from considering them until the next bargaining round scheduled for 2013. Should the mediation process prove unsuccessful a contract would be legislated by the end of July 2012? Before the coolingoff period ended, BCTF president Lambert recommended accepting a mediated agreement to avoid a more punitive legislated one. For Lambert, her union had been bullied into a deal that merely deferred the conflict.

In 2013, a new round of bargaining brought hope for a new beginning. Premier Christy Clark proposed changes to teacher bargaining that included restoring the teachers' right to strike and tied salary increases to those negotiated by a handful of public sector employees such as nurses and college faculty. She also pressed for a 10-year agreement to help stabilize the education system. In January 2013, the government published a framework for the new bargaining process that included a detailed timeline and prescribed mediation without recommendations, and then conciliation with recommendations in case of an impasse. Exhausting these options, the BCTF could then commence a strike in early September, which would postpone the start of the new school year.

In late 2013, the parties were again in Justice Griffin's courtroom. The union argued that Bill 22, which ended the last confrontation, remained unconstitutional because it banned negotiation over the above items until the current agreement expired in June 2013. The union sought reinstatement of these items and unspecified damages. In January 2014, Justice Griffin ruled that the government must pay the BCTF $\$ 2$ million in damages and retroactively restore staffing levels and class size and composition language that had been stripped from the teachers' contract in 2002. Griffin stated that the government did not bargain in good faith after her 2011 ruling.

One of the problems was that the government representatives were preoccupied with another strategy. Their strategy was to put such pressure on the union that it would provoke a strike by the union. The government representatives thought this would allow the government to gain political support for imposing legislation on the union (Summary. British Columbia Teachers' Federation, 2014).

Justice Griffin found that not only had the Clark government disregarded the teachers' rights but had also sought political gain by orchestrating a failure in the collective bargaining process.

This seriously undermined the Premier's legitimacy, and the government's hasty decision to appeal Justice Griffin's decision signaled further hostility. (Note, in April 2015, the BC Court of Appeal backed the government in its appeal and overturned the Griffin decision. BCTF appealed that decision to the Supreme Court of Canada. In November 2016, the Supreme Court overturned the 2015 Court of Appeal decision and reinstated the 2014 Griffin decision.) Any hope of charting new territory was soon lost as the parties returned to the well-trod terrain of acrimony. The union chose to continue their fight through a three-step collective action. In April 2014, it began a province-wide controlled strike (i.e., withdrawal of certain services); in mid-May, it proceeded to rotate strikes, culminating in an all-out strike in mid-June. The government did not pull its punches. On May 26, it implemented a partial lockout. The teachers could not come to work more than 45 minutes before classes start or stay later than 45 minutes after classes end except for an urgent safety issue. In September, the strike ended with both parties claiming victory and signing a new collective agreement.

\section{Data and methodology}

The two labor conflicts were selected for several reasons. First, in both instances, the union and the provincial government remained unchanged. Second, the fundamental issue(s) persisted and, except for the change in union presidency, the key players remained intact. Third, since Susan Lambert immediately preceded Jim Iker, the socio-political context remained similar. Fourth, in both instances, collective action occurred with union members taking strike action against their provincial employer. Finally, both union presidents were cited regularly and often in the press, enabling us to collect data suitable for our analysis. In sum, the conflicts provided a tailor-made opportunity to compare the discourse of a male and female union president under relatively similar conditions.

Newspapers, the Internet edition of the Canadian Broadcasting Corporation (CBC), and union and government 
Vol: 2, Issue: 6

June/2021

https://ijbssrnet.com/index.php/ijbssr

DOI: http://dx.doi.org/10.47742/ijbssr.v2n6p1

news releases are the sources of our data. We searched for news items that occurred between mid-2011 and September 2014. We also searched regularly the government and union websites for news releases with relevant utterances. An utterance comprised all the information provided by the union president in a given article. Unlike Lambert, Iker issued four appeals to action in which he directly addressed union members and urge them to support his action plan. Although we have carefully read over these documents, we have not included them in our analysis since they are unique to Iker. In these appeals, he described the aggressive steps that the government was taking to quell the union's voice and presented a stirring rationale for why members must embrace escalating job action, up to and including a full-out strike. Given the complexity and singularity of Iker's four appeals, we believe that they should be dealt with elsewhere.

Heilman and Okimoto (2007: 81) describe the presence of "stereotype-based 'oughts' about how women should behave," and Brescoll (2016) detailed the two themes, communality and agency, that compose them. In structuring our analysis, we draw upon the themes of agency and communality, but given their mutuality, we explore them in a single section. Thus we interrogated the data to discern whether and how Iker and Lambert differed in their use of these two themes. Communality is a stereotype attributed to women. It specifies that women should exhibit 'nurturing and socially sensitive attributes that demonstrate concern for others, such as being kind, sympathetic, and understanding' (Heilman \& Okimoto, 2007, 81). Agency, on the other hand, is associated with the male but not with female leaders. Agentic behavior, which demonstrates 'dominance, competitiveness, and achievement orientation, is generally considered out of bounds for women' (Heiman \& Okimoto, 2007, 81). Communality and agency are not mutually exclusive they can co-exist in any discourse. What distinguishes speakers is how and to what degree they mobilize these two themes.

Given that labor conflict is the context of this study, we have identified polarization as an additional and critically important theme, since without polarization conflict is not possible. Orienting a group to the conflict requires the construction of an opposing force. Put simply, a definition of "us" requires a definition of "them." To set a group against an "other" requires that salient differences be ascribed, divergent values allotted. Dedaic (2003) describes polarization as the process through which in-groups and out-groups are constructed, members identified and motives assigned. In such a construction, much latitude exists. Not only must a speaker locate topics that resonate with the in-group, but the degree of difference between the groups can also be exaggerated or minimized. We use polarization to identify whether, and to what degree, Iker and Lambert differed in their attempts to construct the government as an "other," as an entity sharing little or much in common with the BCTF.

\section{Communality and agency}

In their survey, Kirton and Healy (2012: 987) found many of their female respondents expressing the need to develop their leadership model, one that was "more sensitive to opening lines of communication and building consensus from the bottom up," which may indicate dissatisfaction with existing maledominated, top-down leadership models. Rather than "taking charge" of members, communication and consensus manifest concern with "taking care" of them, which locates agency with the members rather than the leader. In this scenario, authority rests on the collective will of members, which the leader elicits and fosters.

Replying to questions of what specific action(s) the union was going to take, Lambert stated, "I am not going to be a bit more specific because our decisions are made by our members. But I can tell you members are bringing a whole range of ideas. Every one of them will be canvassed exhaustively that's what we do and the membership will decide" (Bailey \& Hunter, 2012). Lambert did not threaten that strike action was imminent or that the BCTF would be ramping up the pressure but rather emphasized that every member's voice would be heard and that the final decision rested with members, not the union leadership. Lambert cast her presidential role as that of facilitator, one who would canvass the members to collect a range of ideas upon which the ultimate decision would rest. Presumably, her rhetoric invited members to make their voices heard while assuring them of their agency in the final decision of how to respond to the government.

Lambert's utterances presented her as consulting with members concerning the best course of action. She did not tell members what action would be taken. If there were harsh and unpopular decisions to be made, they would be made by the members, not her. When informing the public that the union would be taking strong action, Lambert emphasized that "[w]e [the union] are a democratic organization. We will consult our members as this whole situation unfolds ... Sometimes even though you are afraid, even though the threats are overwhelming, you just have to stand up to a bully" ( $C B C N e w s$ a). The symbolic gravitas of standing up for what is right was discursively transferred to the members. They were the agents of heroic action the president was the vessel through whom their action was articulated and coordinated.

Accordingly, when describing how teachers would conduct their protests Lambert stated that "they will be organizing meetings in front of the schools early in the mornings, and maybe some leafleting and then some general meetings and study sessions and planning sessions" (CBC News $b)$. The agentic activities she described were attributed to union locals, not the BCTF leadership. Lambert noted that she did not know if there would be 'leafleting' or not since it was up to the locals to decide, and they were the ones who would oversee the organizing, meeting, and planning. She was a coordinator, or skillful tactician, balancing the competing demands of commonality and agency.

That is not to say that it was only the members who were working hard, yet when ascribing agency Lambert kept the focus on members. Responding to the government's decision to legislate an agreement, Lambert declared that the union leadership had "been working very hard ... to dissuade the 
government from legislating a collective agreement and we felt ... that this is the worst possible outcome and yet, Minister Abbott has persisted" ( $C B C$ News $d$ ). Presumably, as president, Lambert had also been working hard. But she did not shine the spotlight on her efforts or draw attention to the magnitude of her responsibility and resolve. It was the union leadership, not only the president that had been working hard. That the minister had 'persisted' in bringing to fruition 'the worst possible outcome' was not a failing on the union's part, but rather a sign that their cries had fallen on the deaf ears of a powerful antagonist.

As her union's main spokesperson, Lambert expressed her abiding concern for the emotional toll the conflict was having on BCTF members. She explained that teachers had decided to not issue report cards "very reluctantly' but members felt they must respond to the government's appalling disrespect for the profession of teaching, for students, and public education in BC" (BCTF). Lambert did not hesitate to take care of her members by empathizing with their innermost fears. She understood that members might "be afraid" of this "bully" and sought to reassure them that though they may feel overwhelmed they were answering a higher, nobler call. In this way, Lambert may have hoped to let members know that she 'felt their pain' while reassuring them that 'standing up to this bully was the right thing to do. In so soothing members, she framed the conflict in terms of a noble union protecting vulnerable children from the actions of a self-interested and powerful government. Though members might feel overwhelmed and frightened Lambert reiterated that it was teachers" "professional obligation to stand up on behalf of the kids. That's who we stand for" (Hutchinson, 2012).

Unlike Lambert, Iker did not indicate any intention to consult with members regarding the union's course of action. Rather, he drew attention to the critical role that he was playing in the conflict and his commitment to forcing the government's hand: "There are six days left before the first schools shut down. I encourage Christy Clark and Peter Fassbender to be in touch, move off their unreasonable demands, and empower BCPSEA to negotiate a fair deal" (Laanela, 2014). In providing the government with a deadline Iker presented himself as an aggressive leader who would not shy away from confronting a powerful government opponent. He spoke as one who knew he had the union's full support. Iker did not publicly address the moral qualms or emotional reservations that members may have felt toward presenting the government with such a deadline. Rather he emphasized his agency. Commenting on imminent strike action Iker mused, "my biggest hope is that I have to rush to the airport, get on a plane and head back to Vancouver because the government has finally agreed to let mediation go ahead" (Bailey, 2104). In this instance, Iker emphasized his agency, presenting himself as a "white knight" who would "rush to the airport" to save the day. He also characterized himself as a very busy person conducting important business on the union's behalf, yet he would change his schedule to meet with the opponent whose hand he had forced.

Iker would not compromise on securing less than a fair deal for his members. Negotiation, for instance, was all about "having that (wage) discussion and tabling proposals back and forth at the bargaining table. We also look forward to reaching a fair deal for teachers which includes better supports for our students ... I'm hoping that's the back and forth we can have with the government" (Sherlock, 2014). Securing a fair deal for teachers would be accomplished at the bargaining table where proposals would be sent back and forth between the union leadership and the government. He and his negotiation team were the key players while no mention was made of the role members might play in the process.

When that back and forth did not occur, Iker used strong language to inform his audience that the union was taking strike action: "[This week] pickets will be up in full force across the province. We've asked our locals to ramp up the pressure on school boards and local MLAs" (Bailey, 2014). Unlike Lambert, Iker did not pull his punches the pickets would be "up in full force" and locals would "ramp up the pressure." Although Iker said that locals had been 'asked,' it was framed as less a question and more of a directive, given the assertion that pickets would not be up. Members' response was a given: what the president asked would be done.

Two months earlier Iker had outlined what he believed were the key ingredients to secure the union's demands: "We believe that the combined actions of bargaining hard and the solidarity of standing together are the key ingredients needed to get a deal that works for teachers and our students before June 30" (CBC News c). For Iker, securing a deal would require the members to stand together so that the leadership could pursue "hard" bargaining. The central activities attributed to members were standing in unison and putting pressure on local school boards and MLAs, rather than such activities as organizing, meeting, and planning.

The reactive role members were expected to play was further reflected when members were asked to endorse the president's action plan. On February 28, 2014, Iker emailed a call to action entitled, Fair Deal For Teachers: Better Support for Kids, in which he asked teachers to vote on a three-phase plan. Eighty-nine percent of those voting supported his appeal (Sherlock, 2014). Phase one was not intended to disrupt the classrooms, but teachers would cease providing certain services, like supervising students outside of regularly scheduled classes or attending any meetings with management. Barring significant progress toward a negotiated agreement, collective action would escalate into phase two - rotating strikes. Each local union would fully withdraw services one full day each week. On May 26, Iker emailed another call to action, Keep Calm and Carry on, calling upon union members to participate in the rotating strikes, a called teacher promptly answered.

According to Iker's plan, without progress at the bargaining table collective action would proceed to phase three a province-wide strike that would require a vote of the membership. On June 4 and 5, Iker asked the teachers if they were in favor of escalating job action up to and including a full withdrawal of services. His messages were entitled It's Time to Vote, and Standing Up for Ourselves, Standing Up for Our 
Students. Of those voting, $86 \%$ were in favor of an all-out strike (BCTF, 2014). A full-scale strike began on June 17, 2014. In presenting his three-stage plan, Iker asked teachers for their endorsement via voting and participation, but he gave no indication that he had or would consult with members on the essence of his plan.

So far, our analysis suggests that in their totality, the differences between Lambert and Iker reflects the work of those who like Gray (2001: 135) found that "the overwhelming consensus among union leaders interviewed [was that women brought] a distinctively more open, participatory, and peoplecentered approach to their leadership roles." This distinction was further reflected within the context of deciding how to respond to the government and direct employer. In this regard, Lambert's rhetoric was more sensitive to intra-organizational dynamics and member emotions. She reminded members that they were the ones driving the union's response while validating the mixed emotions they may have had toward the conflict. Her utterances often seemed directed toward an inner, union audience rather than towards a government antagonist.

By contrast, Iker's utterances were primarily interorganizational. They lacked emotional considerations and were directed mainly at the government. In recounting the history of the conflict Iker stated, "we were at the table 78 times in the 20112012 school year, trying to get an agreement. We're trying to rebuild the whole relationship with this government, so you have to question where are the trust and the integrity (Sherlock, 2013)? The participation that Iker emphasized concerned the relationship between the union and the government, not the relationships within the union itself. Throughout the data, Iker did not describe how decisions were or had been made within the union; neither did he respond publicly to any emotional reservations that members may have had with his three-phase plan. Rather, Iker spoke as though he knew the "will of the organization," and would do whatever he thought was required to secure what he believed was the ultimate goal, a fair collective agreement.

\section{Polarization}

"Every dispute," Dedaic (2003:1) argues, starts with "othering," and "othering requires a distinction between 'us' and 'them." Polarization refers to speakers' discursive efforts to construct their group as different and often superior to another group(s), marking and enforcing boundaries between "us" and "them" in terms of motives, values, identities, etc. Polarization is not static. Some speakers may use more polarizing language than others to exaggerate the differences between groups and pass judgment. Polarization fulfills the basic human need to feel that one belongs to a certain group that is perceived as distinct and different from other groups.

Naturally, speakers present themselves and their group positively, often depicting their group as incarnating and/or protecting society's deepest values, while portraying the other group negatively and/or as outsiders that hold an aberrant view. As Reyes (2011: 785) notes, such a binary construction allows "speakers to create two sides of a given story/event," establishing a context "in which speaker and audience are in the 'us-group' and the social actors depicted negatively constitute the "themgroup." In other words, polarization establishes an inclusive "us" and an exclusive "them." Only after sides are constructed is it possible to reject "them" and dismiss what "they" are saying and doing. Chilton (2004) defines this process as "binary conceptualization," while Lazar and Lazar (2004) refer to it as "discursive bipolarity." In both instances, the identity of who "we" are is constructed in terms opposite to who "they" are. For Dediac (2003: 1) the language of polarization asks us to direct the spear towards "the other.",

How does such antagonistic use of language square with our core research question? Both Lambert and Iker characterized the union as virtuously defending the province's children from a rapacious and heartless government intent on balancing its books at any cost. Throughout, Lambert characterized the government as a cynical, self-interested entity guided by political expediency, not educational effectiveness. In responding to the government's decision to legislate a collective agreement, for instance, Lambert characterized its action as the 'height of political cynicism. It's much more of a political act than it is an education act. The punitive fines for contravention of the act are outrageous and a deliberate attempt to intimidate, bully and bludgeon' ( $C B C$ News $d$ ). The government refused to consult with teachers, parents, or students; it was driven solely by self-interest. If the government was not stopped it would trample underfoot public education, workers' rights, democracy, and even the laws of the land.

Iker's language resonated similarly. Responding to his government's decision to appeal the court's decision, Iker argued that such action "showed total disrespect for the law, for teachers, and students. For 12 years teachers have worked to defend our rights, our working conditions, and our students' learning conditions, and once again we find ourselves facing a government focused only on confrontation." (CBC News $e$ ). Iker also invoked government actions in other areas to cast aspersions on its priorities: "the government needs to rethink its priorities and put kids first. If they can build a roof over BC Place [sports stadium] for half a-billion dollars or give a private power company in California $\$ 750$ million, we can afford to invest in our children" (Burgmann, 2014). As with Lambert, Iker constructed government as an out-group whose values were an aberration.

Throughout the data, both Iker and Lambert characterized the government as a bully. Rather than collaborate with the custodians of public education it opted to confront and contradict them. It was a surly antagonist that did not respect teachers, children, or even the legal system, which left the teachers' union to stand alone for what was right and true. Unlike its obstinate foil, the union was portrayed as flexible in its approach and sincere in its demands. For Lambert, "every single one" of the union's objectives was negotiable: "[w]e are ready to compromise on every single one, including salary, including everything. And this government won't compromise by an inch, and on top of that they want to strip our collective agreement of basic hard-won rights" (Steffenhagen \& Fowlie, 2012). But while 
Vol: 2, Issue: 6

June/2021

https://ijbssrnet.com/index.php/ijbssr

DOI: http://dx.doi.org/10.47742/ijbssr.v2n6p1

the union was ready to compromise on "everything" the government would not budge on anything; furthermore, it wanted to reach back in time to strip teachers of their "basic hard-won rights."

Iker reiterated that his union wished to "negotiat[e] a fair and reasonable settlement at the bargaining table ... [t] eachers know that bargaining is about compromise, but we cannot be the only ones expected to move" (Bains, 2014). Teachers were willing to negotiate so that a "fair and reasonable" settlement could be reached, but reciprocation was necessary. Unlike communality and agency, where Lambert used different linguistic choices, polarization revealed little difference between Lambert and Iker. Both used masculine language to juxtapose the selfish interests of government and the selfless interests of the union.

Iker and Lambert constructed government as an outgroup whose values were opposed not only with those of the union, but also those of society. Presumably, such values as democracy, negotiation, justice, and caring, would also be endorsed by the average person. In this way, the union presidents used language that likely portrayed the union as incarnating the values of the public, so that in standing up to the government the union was standing on behalf of the public themselves. Not only did such a portrayal underline the common ground shared by union and citizenry, but also it further alienated the alleged interests of the government, casting it as an exclusive group whose interests were out of sync with the public good.

In sum, within the context of polarization, we found few, if any, differences between Lambert and Iker's language when constructing the government out-group. Both speakers used a similar style to assign motives, values, and roles to solidify the identities of government and union and set them on a collision course. Thus polarization appeared to transcend gender idiosyncrasies.

\section{Summary and Conclusion}

In this paper, we have asked whether and how gender may influence the language union leaders used to enact leadership during a time of conflict. To answer that question, we have analyzed the language that a male, Jim Iker, and female, Susan Lambert, BCTF president used to address their members in two consecutive conflicts with the same government and direct employer. We found that Lambert presented herself as more consultative with members than Iker when the context concerned the union's appropriate reaction to the government. However, these differences disappeared when the presidents constructed the conflict through polarization.

For some scholars, "the idealized feminine way is to lead collaboratively, not to be leading battles to 'save' others" (Kirton \& Healy, 2012: 982). As a male, Iker embraced the agentic role of savior, presenting himself as a "take charge" president that took for granted his member's support to force the government to bend its knee and save public education. If members had reservations, they were not publicly addressed or validated. Iker did not mention whether he had consulted members on the essence of his three-stage action plan with which they were presented, rather he asked them to endorse and execute it. Throughout the conflict, Iker focused on inter-rather than intraorganizational dynamics and emphasized the critical role he was playing in representing the union's demands and standing up to the government.

By contrast, Lambert positioned herself as a facilitator and coordinator of the member's actions, which supports Fletcher's (2004: 650) contention that women are more likely to engage in "postheroic leadership in which the notion of power is re-envisioned from "power over to power with." Unlike Iker, Lambert portrayed herself as more reliant on members, who were the agents driving the protest. It was the members who were shaping the union's response. In addition, Lambert expressed a greater consideration of the members of the reservation may have had with collective action. She acknowledged that teachers may be reluctant to walk away from their students, that they may feel overwhelmed, even frightened with confronting their government. But she reminded them that they had chosen to embark on a noble course to defend their students and public education and that they were actively engaged in determining the union's response.

Yet differences between Iker and Lambert's language were not noticeable when examined within the context of polarization. Lambert's language was as militant and aggressive as Iker's when identifying government as a selfish adversary abusing its legislative powers at the expense of public education and justice. Both leaders framed their government as a bully that was balancing its books on the backs of the province's children. Both presidents used strong, polarizing language to portray the government as an aggressive out-group operating beyond the pale of societal norms. It was not only sacrificing students' wellbeing but was also imperiling the public institutions of democracy, justice, and education.

What may account for the differences between the discourse of polarization (no major differences between the presidents) and the discourse of commonality and agency (noticeable differences)? As far as polarization is concerned, it should be borne in mind that, generally, the position of union president likely demands leaders capable of presenting a strong persona. The acrimonious relationship between the BCTF and the provincial government had established a clear context for union leadership. Before Iker or Lambert had been elected president the battle lines between union and government had been drawn, the adversaries defined and the issues are known. It is doubtful that either Lambert or Iker would have been elected president had they campaigned on a platform of cooperation and compromise with the government antagonist. Perhaps, then, the existing context served as a filter to exclude those females and those males who were not fluent in the language of polarization or who were unwilling to use such strong language.

On the other hand, the decision concerning the appropriate way to retaliate provided the presidents with an opportunity to enact their unique leadership styles. Then we detected differences that might be attributed to gender. Yet it may also be the case that these differences can be attributed to two 
Vol: 2, Issue: 6

June/2021

https://ijbssrnet.com/index.php/ijbssr

DOI: $\underline{\text { http://dx.doi.org/10.47742/ijbssr.v2n6p1 }}$

different leadership styles. Thus further research should range of possible rhetorical responses that may lead to similar corroborate our findings because, in the end, conflict may offer a outcomes regardless of the speaker's gender.

\section{REFERENCES}

Bailey, I. (24 Aug 2014). B.C. teachers' union to escalate strike action in effort to speed negotiations. The Globe and Mail.

Bailey, I. \& Hunter, J. (15 Mar, 2012). Extracurriculars in crosshairs as B.C. passes bill banning teacher strikes. The Globe and Mail.

Baines, C. (28 May 2014). B.C. teachers to continue rotating strikes next week.' CTV News.

BCTF. (10 June 2014). BC Teachers Vote Overwhelmingly in Favor of Strike Escalation.

Billing, M. (2003). Preface: Language as forms of death. In M. N. Dedaic \& D. N. Nelson (Eds), At war with words. Berlin: Mouton de Gruyter, vii-xxii.

Billing, Y.D. \& Alvesson, M. (2000). Questioning the notion of feminine leadership: A critical perspective on the gender labelling of leadership. Gender, Work \& Organization 7(3): 144-157.

Brescoll, V. (2016). Leading with their hearts? How gender stereotypes of emotion lead to biased evaluations of female leaders. The Leadership Quarterly 27: 415-428.

Briskin, L. (2011). Union renewal, postheroic leadership, and women's organizing: Crossing discourses, reframing debates. Labor Studies Journal 36(4): 508-37.

Briskin, L. (2006) Victimisation and agency: The social construction of union women's leadership. Industrial Relations Journal 37(4): 359-378.

British Columbia Teachers' Federation. (1 March 2012). News release.

British Columbia Teachers' Federation v. British Columbia. (2011). BCSC 469.

British Columbia Teachers' Federation v. British Columbia. (2014). BCSC 121.

Burgmann, T. (4 Sept 2014) B.C. teachers' union rejects premier's call to end strike and bring 'reasonable' proposal to bargaining table. The National Post.

CBC News a. (1 Mar 2012). B.C. teachers to start 3-day strike Monday.

CBC News b. (5 Mar 2012). B.C. teachers' strike begins with no rush for legislation.

CBC News c. (10 Jun 2014). B.C. teachers to begin full-scale strike Tuesday.

CBC News d. (28 Feb 2012). B.C. legislation to remove teachers' right to strike.

CBC News e. (25 Feb 2014). B.C. teachers' strike vote to be held in March.

Chilton, P. (2004). Analyzing political discourse. London: Routledge.

Cobble, D. (2004) The other women's movement: Workplace justice and social rights in modern America. Princeton NJ and Oxford: Princeton University Press.

Daily Bulletin. (30 June 2011). Strike vote gets massive support from B.C. teachers.

Dediac, M. (2003). Introduction: A peace of word. In M.N. Dediac \& D.N. Nelson (Eds), At War with words. Berlin: Mouton de Gruyter: 1-26.

Eagly, A. \& Heilman, M. (2016). Gender and leadership: Introduction to the special issue. The Leadership Quarterly 27: $349-353$.

Eagly, A. \& Carli, L. (2003). Women and the labyrinth of leadership. Harvard Business Review 85(9): 62-67.

Eagly, A. \& Johannesen-Schmidt, M. (2001). The leadership styles of women and men. Journal of Social Issues 57(4): $781-797$.

Fairhurst, G. (2009). Considering context in discursive leadership research. Human Relations 62(11): 1607-1633.

Fitzpatrick, T.A. \& Curran, C.R. (2014). Waiting for your coronation: A career-limiting trap. Nursing Economics 32(3): $162-165$.

Fleming, T. (2011). Worlds apart: British Columbia schools, politics, and labour relations before and after 1972. British Columbia: Bendall Books.

Fletcher, J.K. (2004). The paradox of postheroic leadership: An essay on gender, power, and transformational change. The Leadership Quarterly 15: 647-661.

Gee, J.P .(2011). An Introduction to discourse analysis: Theory and method. $3^{\text {rd }}$ Ed. New York: Routledge.

Graham. P, Keenan. T. \& Dowd, A.M. (2004). A call to arms at the end of history: a discourse-historical analysis of George W. 
Vol: 2, Issue: 6

June/2021

https://ijbssrnet.com/index.php/ijbssr

DOI: $\underline{\text { http://dx.doi.org/10.47742/ijbssr.v2n6p1 }}$

Bush's declaration of war on terror. Discourse \& Society 15(2-3): 199-222.

Grant, D., Keenoy, T. \& Oswick. C, (1998), Defining organizational discourse: Of diversity, dichotomy and multi-disciplinarity. In G. D. Keenoy \& Oswick, C (Eds), Discourse and Organization. Thousand Oaks: Sage: 1-13.

Gray, L. (2001). Women in union leadership. In C. Costello \& A. Stone (Eds), The American woman, 2001-2002. New York: W.W.

Norton: 107-138.

Habermas, J. (1977). Understanding and social inquiry. F. Reinhard. (Trans), Notre Dame: University of Notre Dame Press. Harriford, D. (1993) Comments. In D. Cobble. (Ed). Women and unions: Forging a partnership. Ithaca, NY: ILR Press: 402-405. Health Services and Support -- Facilities Subsector Bargaining Assn. v. British Columbia (2007) SCC 27.

Heilman, M.E. (2001). Description and proscription: How gender stereotypes prevent women's ascent up the organizational ladder. Journal of Social Issues, 57(4): 657-674.

Holmes, J. (2006). Gendered Talk at Work. Oxford: Blackwell.

Holmes, J. \& Stubbe, M. (2003). Power and Politeness in the Workplace: A Sociolinguistic Analysis of Talk at Work. London: Longman.

Hoyt, C. \& Murphy, S. (2016) Managing to clear the air: Stereotype threat, women, and leadership. The Leadership Quarterly 27(3) 387-399.

Hutchinson, B. (23 Mar 2012). B.C. teachers' ceasefire unravels. The National Post.

Kanter, R. (1977). Men and women of the corporation. Basic books: New York.

Kelly, J. (1998). Rethinking industrial relations: Mobilization, collectivism and long waves. New York: Routledge.

Kimmel, M. (1994). Masculinity as homophobia: Fear, shame and silence in the construction of gender identity. In D. Collinson \& J. Hearn (Eds), Men as managers, managers as men. London: Sage.

Kirton, G. (2006). The making of women trade unionists. Aldershot: Ashgate.

Kirton, G. \& Healy, G. (2012). 'Lift as you rise': Union women’s leadership talk. Human Relations 65(8): 979-999.

Korabik, K. (1990). Androgyny and Leadership Style. Journal of Business Ethics, 9(4-5): 283-292

Kramarae, C. \& Healy, G. (1985). A Feminist dictionary. Boston, MA: Pandora Press.

Laanela, M. (20 May 2014). B.C. teachers to start rotating strikes next week. CBC News.

Lazar, A. \& Lazar, M. (2004). The discourse of the new world order: 'Out-casting' the double face of threat. Discourse \& Society 15(2-3): 223-242.

Luk, V. (27 Jan 2014). B.C. fined \$2-million for lack of good faith in talks with teachers. The Globe and Mail.

McAdam, D. (1982) Political process and the development of black insurgency 1930-1970. Chicago: University of Chicago.

Meyer, M. (2001) Between theory, method, and politics: Positioning of the approaches to CDA. In R. Wodak \& M. Meyer (Eds), Methods of critical discourse analysis. Thousand Oaks, California: Sage: 14-31.

Mullany, L. (2007). Gendered Discourse in Professional Communication. Basingstoke: Palgrave.

Mumby, D. (1998). Organizing men: Power, discourse, and the social construction of masculinity(s) in the workplace. Communication Theory 8: 164-183.

Mumby, D. \& Clair, R. (1997). Organizational discourse. In T.A.Van Dijk (Ed), Discourse as social interaction. Discourse studied: A multidisciplinary introduction (vol 2). Thousand Oaks: Sage, 181-205.

Mumby, D. \& Putnam, L. (1992). The politics of emotion: A feminist reading of bounded rationality. Academy of Management Review 17: 465-486.

Nelson, D. (2003.) Conclusion: Word peace. In M. N. Dediac \& D. N. Nelson (Eds), At war with words. Berlin: Mouton de Gruyter, 449-462.

Phelan, S. (1993). (Be)coming out: Lesbian identity and politics. Signs 18(4): 765-790.

Potter, J. \& Wetherell, M. (1987). Discourse and social psychology: Beyond attitudes and behavior. Beverly Hills: Sage.

Reshef, Y. \& Keim, C. (2016) Bad time stories: Government-Union conflicts and the rhetoric of legitimation strategies. Toronto: University of Toronto Press.

Reyes, A. (2011). Strategies of legitimization in political discourse: From words to actions. Discourse \& Society 22(6): $781-807$.

Sandberg, S. (2013). Lean In: Women, work, and will to Lead. New York, NY: Alfred A. Knopf. 
Vol: 2, Issue: 6

June/2021

https://ijbssrnet.com/index.php/ijbssr

DOI: http://dx.doi.org/10.47742/ijbssr.v2n6p1

Sealy, R. Vinnicombe, S. \& Singh, V. (2008). The Female FTSE Index and Report 2008. London: Cranfield University School of Management.

Sherlock, T. (18 Nov 2013). BCTF says province tried to provoke strike during 2011 job action. Vancouver Sun.

Sherlock, T. (7 Mar 2014). B.C. teachers vote in favour of strike; province waiting for union to table demands. Vancouver Sun.

Snow, D.A. Rochford, R.B., Worden, S.K. \& Benford, R.D. (1986). Frame alignment processes, micromobilization, and movement participation. American Sociological Review 51: 464-481.

Snow, D.A. \& Benford, R.D. (1988). Ideology, frame resonance, and participant mobilization. International Social Movement Research 1: 197-217.

Schnurr, S. (2008). Leadership Discourse at Work: Interactions of Humour, Gender and Workplace Culture. Basingstoke: Palgrave. Steffenhagen, J. \& Fowlie, S. (7 Mar 2012). Education Minister offers to talk to teachers' union boss about bill concerns. Vancouver Sun.

Stueck, W. (7 Mar 2012). Returning B.C. teachers vow to keep up pressure against Bill 22. The Globe and Mail.

Tannen, D. (1990). You just don't understand: Women and men in conversation. New York, NY: Morrow.

Vancouver Sun. (9 Sept 2013). B.C. teachers say government didn't comply with court order over class size.

Vial, A. Napier, L. \& Brescoll, V. (2016). A bed of thorns: Female leaders and the self-reinforcing cycle of illegitimacy. The Leadership Quarterly 27: 400-414.

Wajcman, J. (1998). Managing like a man: women and men in corporate management. University Park, PA: Pennsylvania State University Press.

Watson, T. (2010). Reputation models, drivers, and measurements. In R. Tench \& L. Yeomans (Eds), Exploring public relations, 2nd Ed. Harlow: Pearson: 339-351.

Williams, C. (2002). Masculinities and emotion work in trade unions. In F. Colgan \& S. Ledwith (Eds), Gender, diversity and trade unions. London: Routledge, 292-311.

Wodak, R. (2003). Populist discourses: the rhetoric of exclusion in written genres. Document Design 4(2): 132-148.

Woo, A. (31 May 2014). B.C. teachers, government use funding statistic to tell different stories. The Globe and Mail. 